\title{
Genome of Serratia plymuthica UBCF_13, Insight into diverse
}

\section{unique traits [version 1; peer review: 1 not approved]}

\author{
Raudhatul Fatiah1, Irfan Suliansyah2,3, Djong Hon Tjong,3,4, Lily Syukriani², \\ Roza Yunita2, Robi Trivano2, Nurefni Azizah², Jamsari Jamsari11,3 \\ ${ }^{1}$ Agricultural Science, Universitas Andalas, Padang, West Sumatera, 25163, Indonesia \\ ${ }^{2}$ Agrotechnology, Agricultural Faculty, Universitas Andalas, Padang, West Sumatera, 25163, Indonesia \\ ${ }^{3}$ Biotechnology Magister Program, Universitas Andalas, Padang, West Sumatera, 25163, Indonesia \\ ${ }^{4}$ Biology, Mathematics and Life Sciences Faculty, Universitas Andalas, Padang, West Sumatera, 25163, Indonesia
}

\author{
V1 First published: 18 Aug 2021, 10:826 \\ https://doi.org/10.12688/f1000research.54402.1 \\ Latest published: 18 Aug 2021, 10:826 \\ https://doi.org/10.12688/f1000research.54402.1
}

\section{Abstract}

Background: Whole genome sequencing is become an essential tool to explore potential of microorganism and evolutionary study. The Serratia plymuthica UBCF_13 is one of phylloplane associated plant bacteria showing antifungal activity. For that reason, its complete genome information is necessary to enhance its potential as biocontrol against plant pathogenic fungal. Here, we report the genome sequence of Serratia plymuthica UBCF_13 to understand the molecular mechanism regarding its biocontrol ability.

Methods: Continuous short reads were attained from Illumina sequencing runs and reads $150 \mathrm{bp}$ were merged into a single dataset. Pan-genome based method was used to identify core-genome of $S$. plymuthica species and unique gene in UBCF_13.

Results: Assambled Illumina reads of S. plymuthica strain UBCF_13 genome was produced a $5.46 \mathrm{Mb}$ circular genome sequence. It was found 3321 genes belong to the core-genome sheared by the 18 strains evaluated. The UBCF_13 genome harbor 485 unique genes, where 300 of them only can be found in this strain

Conclusions: The sequence of UBCF_13 genome sequence data will contribute for further exploration of the potential of S. plymuthica UBCF_13 as bacteria producing antibiotic.

\section{Keywords}

Pan-genomic, core-genome, unique gene, Serratia plymuthica, genome sequencing, comparative genomic

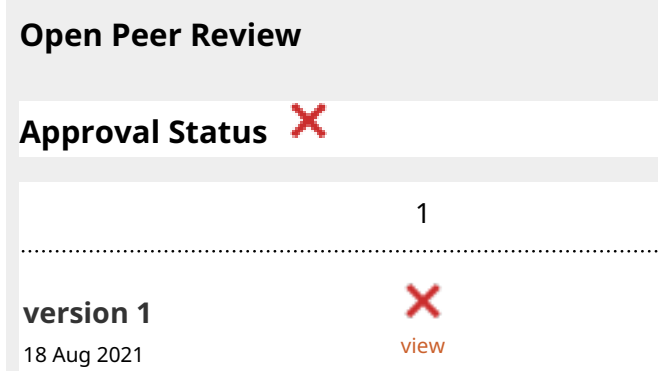

1. Zulema Udaondo iD, University of Arkansas

for Medical Sciences, Little Rock, USA

Any reports and responses or comments on the article can be found at the end of the article. 
Corresponding author: Jamsari Jamsari (jamsari@agr.unand.ac.id)

Author roles: Fatiah R: Data Curation, Formal Analysis, Investigation, Methodology; Suliansyah I: Funding Acquisition, Supervision; Tjong DH: Supervision, Writing - Review \& Editing; Syukriani L: Funding Acquisition, Project Administration; Yunita R: Funding Acquisition, Project Administration, Writing - Review \& Editing; Trivano R: Funding Acquisition; Azizah N: Funding Acquisition; Jamsari J: Conceptualization, Funding Acquisition, Writing - Review \& Editing

Competing interests: No competing interests were disclosed.

Grant information: This study was fully funded by the General Directorate of Higher Education through PMDSU Research Grant Fiscal year 2020 contract number: T/10/UN.16.17/PT.01.03/AMD/ PMDSUPangan/2020 and 01/PL/SPK/PNP/ FAPERTA-Unand/2021 The funders had no role in study design, data collection and analysis, decision to publish, or preparation of the manuscript.

Copyright: @ 2021 Fatiah R et al. This is an open access article distributed under the terms of the Creative Commons Attribution License, which permits unrestricted use, distribution, and reproduction in any medium, provided the original work is properly cited.

How to cite this article: Fatiah R, Suliansyah I, Tjong DH et al. Genome of Serratia plymuthica UBCF_13, Insight into diverse unique traits [version 1; peer review: 1 not approved] F1000Research 2021, 10:826 https://doi.org/10.12688/f1000research.54402.1

First published: 18 Aug 2021, 10:826 https://doi.org/10.12688/f1000research.54402.1 


\section{Introduction}

Serratia plymuthica bacteria have been isolated from many environmental sources and are found associated with diverse plants $^{1-5}$. Many strains of this species have been reported to have the ability to inhibit the growth of plant-pathogenic fungi and stimulate plant growth $^{6-9}$. UBCF_13 is one strain of this species. It has ability to inhibit Colletotrichum gloeosporioides, a species of post-harvest pathogenic fungi that causes anthracnose disease in various plants ${ }^{10}$.

Here, we report the complete genome sequence of this bacterium, constructed using Illumina sequencing technology. Our dataset may be useful as a comparative genome for evolutionary and speciation studies, as well as for the analysis of protein-coding RNA, biosynthetic gene clusters and may also useful for further study such as the regulation of gene expression in relation to the antifungal activity of this bacterium.

\section{Methods}

\section{Genomic DNA isolation and sequencing}

S. plymuthica strain UBCF_13 was isolated from phylloplane of Brassica juncea L. in 2012 from District of Solok, Province of West Sumatera, Indonesia ${ }^{10}$. The bacterium was cultivated in Luria-Bertani (LB) broth at $27^{\circ} \mathrm{C}$ for 16 hours with $150 \mathrm{rpm}$. The genomic DNA was extracted using the method of Chen and Kuo (1993) ${ }^{11}$, followed by degrading residual RNA by RNAse. Library preparation and sequencing was done by Novogen (Hong Kong). Sequencing was performed using Illumina NovaSeq 6000 (Illumina NovaSeq 6000 Sequencing System, RRID:SCR_016387).

\section{Genome assembly and annotation}

Continuous short reads of $150 \mathrm{bp}$ were merged into a single dataset. The dataset was obtained by using combination of map-based gene references and de novo assembly that was performed in Geneious software (Geneious, RRID:SCR_010519) ${ }^{12}$. The annotation in genome submission was carried out using NCBI Prokaryotic Genomes Automatic Annotation Pipeline $(\mathrm{PGAP})^{13}$. The annotated genome sequence of UBCF_13 has been deposited in the NCBI GenBank under accession number CP068771.

\section{Comparative genomics of Serratia plymuthica strains}

Comparative genomics analysis was carried out using genome sequences of UBCF_13 from this research and 17 whole sequenced genomes of other Serratia plymuthica strains retrieved from NCBI's GenBank. The genomes were reannotated using the Prokka software tool (Prokka, Galaxy Version 1.14.6+galaxy0) (Prokka, RRID:SCR_014732) (14,15 $^{1}$ that is available from the NCBI. Identification of genes shared between the strains, and 'presence-absence gene set' was carried out using Roary; Galaxy Version 3.13.0+galaxy1, (Roary, RRID:SCR_018172) ${ }^{16}$ with a threshold similarity of $70 \%$.

Genes that exist in all the strains are the core-genome. Phylogenetic trees were constructed using Maximum Likelihood based inference of large phylogenetic trees-RAxML, Galaxy Version 8.2.4+galaxy2 (RAxML, RRID:SCR_006086) ${ }^{17}$ based on multialignment of concatenate core-genome. Phandango (Phandango, RRID:SCR_015243) ${ }^{18}$ was used to view the resulted output graphs.

\section{Cluster of the orthologous groups of UBCF_13}

The translated protein coding genes of UBCF_13 was used for identification of cluster of orthologous groups (COG). This was obtained from NCBI BLAST+rpsblast (Galaxy Version 2.10.1+galaxy0) ${ }^{19}$ and eggNOG Mapper (Galaxy Version 2.0.1+galaxy1) (eggNOG, RRID:SCR_002456) ${ }^{20}$. The result of COG identification was classified based on the categories in COG database $\mathrm{NCBI}^{21}$.

\section{Result and discussion}

Comparative genomics of Serratia plymuthica strains

The whole genome sequencing reads of Serratia plymuthica UBCF_13 were assembled into a single circular $5.46 \mathrm{Mb}$ chromosome with overall GC content of $56.2 \%$ (Table 1). S. plymuthica has a genome size in the range $5.40-5.70 \mathrm{Mb}$. The GC content percentage is 55.70-56.60. Based on genome reannotation by Prokka, it was found different number of CDS in each genome S. plymuthica (Table 1). All of the compared S. plymuthica genomes shared a highly conserved genomic architecture as inferred from synteny of protein coding orthologs.

Figure 1A shows the phylogenetic tree of 18 strains S. plymuthica. The phylogenetic tree shows that S. plymuthica UBCF_13 is in same cluster with strain AS9, PRI-2C, NCTC8015, and NCTC8900. The strain PRI-2C is reclassified and transferred to the species $S$. inhibens ${ }^{22}$. The pangenome was performed together with other strains in order to obtain further insight into specific features in the UBCF_13. It was found 3315 belong to the core-genome shared by the 18 strains evaluated. The genome of the UBCF_13 harbors 488 unique genes, of which 300 genes are only contained by this strain. The presence-absence gene set was shown in file supplementary data 1

\section{The Cluster of Orthologous Groups of UBCF_13}

Functional categories of the CDS in S. plymuthica UBCF_13 based on the Cluster of Orthologous Groups (COG) categories are shown in Table 2. The list of UBCF_13 COG and its function classification based on COG database was shown in extended dataset $2^{23}$. 
Table 1. Genomic features comparison of Serratia plymuthica strains.

\begin{tabular}{|l|l|l|l|l|l|}
\hline \multicolumn{1}{|c|}{ Strains } & Accessions & Size (Mb) & GC\% & CDSs & \multicolumn{1}{|c|}{ Sources } \\
\hline UBCF_13 & CP068771.1 & 5.46 & 56.20 & 4920 & Phylloplane of Brassica juncea L. \\
\hline 3Re4-18 & CP012097.1 & 5.44 & 56.20 & 4937 & $\begin{array}{l}\text { Endorhiza of Solanum tuberosum } \\
\text { L. CV. Cilena }\end{array}$ \\
\hline 3Rp8 & CP012096.1 & 5.55 & 56.10 & 5071 & Brassica napus \\
\hline 4Rx13 & CP006250.1 & 5.40 & 56.09 & 4831 & The rhizosphere of Brassica napus \\
\hline AS9 & CP002773.1 & 5.44 & 56.00 & 4970 & Rapeseed roots grown in Sweden \\
\hline C-1 & CP053398.1 & 5.70 & 56.10 & 5316 & Capsicum annuum \\
\hline FDAARGOS_889 & CP065699.1 & 5.44 & 56.20 & 4951 & \\
\hline FDAARGOS_895 & CP065688.1 & 5.35 & 55.90 & 4856 & \\
\hline FDAARGOS_896 & CP065747.1 & 5.53 & 55.80 & 5025 & \\
\hline FDAARGOS_907 & CP065673.1 & 5.47 & 55.90 & 4964 & \\
\hline FDAARGOS_1138 & CP068096.1 & 5.48 & 56.17 & 4960 & \\
\hline NCTC12961 & LS483469.1 & 5.35 & 55.90 & 5833 & \\
\hline NCTC8015 & LR134478.1 & 5.33 & 55.70 & 4901 & \\
\hline NCTC8900 & LR134151.1 & 5.32 & 55.80 & 5148 & \\
\hline PRI-2C & CP015613.1 & 5.47 & 55.70 & 5009 & Maize rhizosphere in the \\
\hline S13 & CP006566.1 & 5.47 & 56.20 & 4959 & Raw vegetable-processing line \\
\hline RVH1 & ARW01000001.1 & 5.51 & 56.20 & 5023 & \\
\hline V4 & CP007439.1 & 5.51 & 56.20 & 5073 & $\begin{array}{l}\text { A biofilm of pasteurizer plates of } \\
\text { milk processing machine }\end{array}$ \\
\hline
\end{tabular}

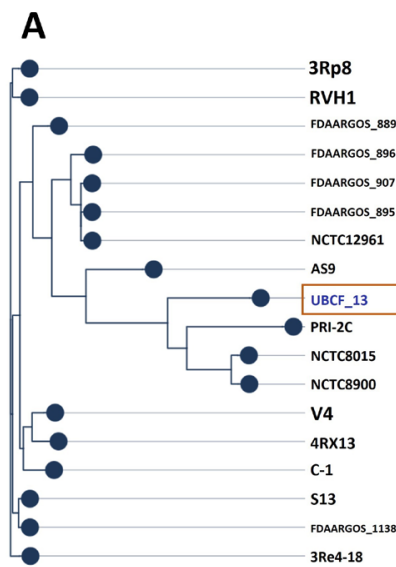

B

Figure 1. Maximum Likelihood tree and visualization of comparative genomic (pan genomic) between 18 strain S. plymuthica. (a) Phylogenetic of 18 strains S. plymuthica based on concatenate core-genome multialignment; and (b) visualization of presence (blue bar)absence (white bar) gene in each of the strains. 
Table 2. Cluster of Ortologous Gene of The UBCF_13.

\begin{tabular}{|c|c|c|}
\hline & Function Class & Number of \\
\hline A & RNA processing and modification & 1 \\
\hline C & Energy production and conversion & 259 \\
\hline D & Cell cycle control, cell division, chromosome partitioning & 61 \\
\hline $\mathrm{E}$ & Amino acid transport and metabolism & 583 \\
\hline $\mathrm{F}$ & Nucleotide transport and metabolism & 120 \\
\hline G & Carbohydrate transport and metabolism & 476 \\
\hline $\mathrm{H}$ & Coenzyme transport and metabolism & 255 \\
\hline I & Lipid transport and metabolism & 215 \\
\hline J & Translation, ribosomal structure and biogenesis & 272 \\
\hline K & Transcription & 526 \\
\hline L & Replication, recombination and repair & 153 \\
\hline M & Cell wall/membrane/envelope biogenesis & 311 \\
\hline $\mathrm{N}$ & Cell motility & 96 \\
\hline O & Posttranslational modification, protein turnover, chaperones & 212 \\
\hline P & Inorganic ion transport and metabolism & 367 \\
\hline Q & Secondary metabolites biosynthesis, transport and catabolism & 125 \\
\hline $\mathrm{R}$ & General function prediction only & 476 \\
\hline S & Function unknown & 178 \\
\hline $\mathrm{T}$ & Signal transduction mechanisms & 233 \\
\hline$U$ & Intracellular trafficking, secretion, and vesicular transport & 82 \\
\hline V & Defense mechanisms & 131 \\
\hline W & Extracellular structures & 30 \\
\hline$x$ & Mobilome: prophages, transposons & 42 \\
\hline Z & Cytoskeleton & 2 \\
\hline- & No COG assignment & 518 \\
\hline
\end{tabular}

\section{Data availability}

Data from Serratia plymuthica UBCF_13 is available at NCBI under Bio-Project PRJNA692765, including the complete genome with annotation at GenBank accession CP068771, and the read data in the Sequence Read Archive (SRA) database under the accession number SRR15012717.

\section{Extended data}

Dataset 1:

Dryad: Gene presence absence in Serratia plymuthica strains. https://doi.org/10.5061/dryad.1zcrjdfsj ${ }^{24}$

This project contains the following extended data;

- Gene_presence_absence_in_Serratia_plymuthica_ strains.csv (This data shows gene presence or absence across strain Serratia plymuthica species. It contains a list of coding protein gene (CDS) name and region where the gene exist in each genome (locus_ tag). The region/locus where the CDS are existing has a specific tag for each genome, whereas the number after locus names represents the order of CDS in each genome. This data could be used to identify conserved and unique genes in Serratia plymuthica.)

- Readme_Gene_presence_absence_in_Serratia_ plymuthica_strains.txt (This text file provides information about the above data)

Dataset 2:

Dryad: Classification of the UBCF_13 COG based on COG database in NCBI https://doi.org/10.5061/dryad.sn02v6x4g 23 
This project contains the following extended data;

- Classification_of_the_UBCF_13_COG_based_on_ COG_database_in_NCBI.csv (This data contains information about the assignment of Clusters of Orthologous Gene (COG) for each coding protein gene in Serratia plymuthica UBCF_13 and their functional classification based on COG database in NCBI)

Data are available under the terms of the Creative Commons Zero "No rights reserved" data waiver (CCO 1.0 Public domain dedication)
1. Neupane S, Högberg N, Alström S, et al.: Complete genome sequence of the rapeseed plant-growth promoting Serratia plymuthica strain AS9. Stand Genomic Sci. 2012; 6(1): 54-62.

PubMed Abstract | Publisher Full Text | Free Full Text

2. Adam E, Müller $H$, Erlacher A, et al.: Complete genome sequences of the Serratia plymuthica strains 3Rp8 and 3Re4-18, two rhizosphere bacteria with antagonistic activity towards fungal phytopathogens and plant growth promoting abilities. Stand Genomic Sci. 2016; 11(1): 61. PubMed Abstract | Publisher Full Text | Free Full Text

3. Cleto S, van der Auwera G, Almeida C, et al.: Genome Sequence of Serratia plymuthica V4. Genome Announc. 2014; 2(3): e00340-14. PubMed Abstract | Publisher Full Text | Free Full Text

4. Neupane S, Finlay RD, Kyrpides NC, et al.: Complete genome sequence of the plant-associated Serratia plymuthica strain AS13. Stand Genomic Sci. 2012; 7(1): 22-30.

PubMed Abstract | Publisher Full Text | Free Full Text

5. de Vleesschauwer D, Chernin L, Höfte MM: Differential effectiveness of Serratia plymuthica IC1270-induced systemic resistance against hemibiotrophic and necrotrophic leaf pathogens in rice. BMC Plant Biol. 2009; 9(1): 9.

PubMed Abstract | Publisher Full Text | Free Full Text

6. Müller H, Fürnkranz M, Grube M, et al.: Genome Sequence of Serratia plymuthica Strain S13, an Endophyte with Germination- and Plant-GrowthPromoting Activity from the Flower of Styrian Oil Pumpkin. Genome Announc. 2013; 1(4): e00594-13.

PubMed Abstract | Publisher Full Text | Free Full Text

7. Kurze S, Bahl H, Dahl R, et al.: Biological Control of Fungal Strawberry Diseases by Serratia plymuthica HRO-C48. Plant Dis. 2001; 85(5): 529-534. PubMed Abstract | Publisher Full Text

8. Vleesschauwer D: Using Serratia plymuthica to control fungal pathogens of plants. CAB Rev Perspect Agric Vet Sci Nutr Nat Resour. 2007; 2(046): 1-9. Publisher Full Text

9. Campos D, Cottet L, Castillo A: Antifungal activity of Serratia plymuthica CCGG2742 against a new wild isolate of the phytopathogenic fungus Alternaria tenuissima. Plant Dis. 2018; PDIS-05-17-0709-RE. Reference Source

10. Aisyah SN, Sulastri S, Retmi R, et al.: Suppression of Colletotrichum gloeosporioides by Indigenous Phyllobacterium and its Compatibility with Rhizobacteria. Asian J Plant Pathol. 2017; 11(3): 139-147. Publisher Full Text

11. Chen WP, Kuo TT: A simple and rapid method for the preparation of gramnegative bacterial genomic DNA. Nucleic Acids Res. 1993; 21(9): 2260. PubMed Abstract | Publisher Full Text | Free Full Text
12. Kearse M, Moir R, Wilson A, et al:: Geneious Basic: An integrated and extendable desktop software platform for the organization and analysis of sequence data. Bioinformatics. 2012; 28(12): 1647-1649. PubMed Abstract | Publisher Full Text | Free Full Text

13. Li W, O'Neill KR, Haft DH, et al.: RefSeq: expanding the Prokaryotic Genome Annotation Pipeline reach with protein family model curation. Nucleic Acids Res. 2021; 49(D1): D1020-D1028.

PubMed Abstract | Publisher Full Text | Free Full Text

14. Cuccuru G, Orsini M, Pinna A, et al.: Orione, a web-based framework for NGS analysis in microbiology. Bioinformatics. 2014; 30(13): 1928-9. PubMed Abstract | Publisher Full Text | Free Full Text

15. Seemann T: Prokka: Rapid prokaryotic genome annotation. Bioinformatics. 2014; 30(14): 2068-9.

PubMed Abstract | Publisher Full Text

16. Page AJ, Cummins CA, Hunt M, et al.: Roary: Rapid large-scale prokaryote pan genome analysis. bioRxiv. 2015; 019315.

Publisher Full Text

17. Stamatakis A: RAxML version 8: a tool for phylogenetic analysis and postanalysis of large phylogenies. Bioinformatics. 2014; 30(9): 1312-1313. PubMed Abstract | Publisher Full Text | Free Full Text

18. Hadfield J, Croucher NJ, Goater RJ, et al.: Phandango: An interactive viewer for bacterial population genomics. Bioinformatics. 2018; 34(2): 292-293. PubMed Abstract | Publisher Full Text | Free Full Text

19. Cock PJA, Chilton JM, Grüning B, et al:: NCBI BLAST+ integrated into Galaxy. Gigascience. 2015; 4(1): 39.

PubMed Abstract | Publisher Full Text | Free Full Text

20. Huerta-Cepas J, Forslund K, Coelho LP, et al.: Fast Genome-Wide Functional Annotation through Orthology Assignment by eggNOG-Mapper. Mol Biol Evol. 2017; 34(8): 2115-2122.

PubMed Abstract | Publisher Full Text | Free Full Text

21. Galperin MY, Wolf YI, Makarova KS, et al.: COG database update: focus on microbial diversity, model organisms, and widespread pathogens. Nucleic Acids Res. 2021; 49(D1): D274-D281.

PubMed Abstract | Publisher Full Text | Free Full Text

22. Hennessy RC, Dichmann SI, Martens HJ, et al.: Serratia inhibens sp. nov., a new antifungal species isolated from potato (Solanum tuberosum). Int J Syst Evol Microbiol. 2020; 70(7): 4204-4211.

PubMed Abstract | Publisher Full Text

23. Raudhatul F, Irfan S, Djong HT, et al:: Classification of the UBCF 13 COG based on COG database in NCBI, Dryad. Dataset. 2021. http://www.doi.org/10.5061/dryad.sn02v6x4g

24. Raudhatul F, Irfan S, Djong HT, et al:: Gene presence absence in Serratia plymuthica strains, Dryad. Dataset. 2021 http://www.doi.org/10.5061/dryad.1zcrjdfsj 


\section{Open Peer Review}

\section{Current Peer Review Status: $\mathrm{X}$}

\section{Version 1}

Reviewer Report 06 December 2021

https://doi.org/10.5256/f1000research.57885.r100842

(C) 2021 Udaondo Z. This is an open access peer review report distributed under the terms of the Creative Commons Attribution License, which permits unrestricted use, distribution, and reproduction in any medium, provided the original work is properly cited.

\section{Zulema Udaondo}

Department of Biomedical Informatics, University of Arkansas for Medical Sciences, Little Rock, Arkansas, 72205, USA

The manuscript by Fatiah et al. is a descriptive study of the novel bacteria with antifungal activity, Serratia plymuthica UBCF_13 that was isolated from the leaf surface of Brassica juncea. The pangenome of this isolate along with another 17 Serratia plymuthica strains downloaded from GenBank was also performed by the authors.

S. plymuthica is a cosmopolite species that have potential applications as a biocontrol agent due to its antifungal activity. Therefore comparative analyses of members of this species are useful to unveil the metabolic characteristics of this interesting microorganism.

Although the manuscript is understandable for the most part, I would strongly recommend a further revision of the manuscript by a scientific editor as there are some sentences in the manuscript that are difficult to understand, hindering the readability of the entire manuscript.

There are also some important data and methodology that are lacking in the manuscript that would be useful from my point of view to better understand the complete context of the study and the reported findings.

For example, one of the main concerns is that when accessing the GenBank accession ID for the UBCF_13 strains provided by the authors, it can be observed in the taxonomy check performed by GenBank staff, that this strain is flagged as "Inconclusive". Thus, when checking the bottom of the Assembly QA tab from the GenBank webpage:

https://www.ncbi.nlm.nih.gov/assembly/GCF_018336935.1\#/qa, this strain is classified as a member of the species Serratia inhibens.

This species is also the one to which the strain PRI-2C was reclassified in 2020 as can be observed in the paper published in the International Journal of Systematic and Evolutionary Microbiology June $2020^{1}$. Thus, it makes sense that these two strains are grouped together in the tree shown by 
the authors. The isolates NCTC8900 and NCTC8015 also failed their taxonomy check, being identified as well, as members of Serratia inhibens species, thus it makes sense that these four strains form a monophyletic group in the tree. These are important issues that I believe should be addressed by the authors. Also, this information could help clarify some of the information obtained by the authors in their pangenome analysis.

On the basis of the above, I think it is crucial to provide in the methodology how isolate UBCF_13 was identified as a member of S. plymuthica by the authors.

Another issue that I believe would help the authors increase the confidence of their analysis is to provide a quick explanation about the selection of the strains employed in their pangenome analysis. So far there are 29 available genomes classified as S. plymuthica in GenBank, however, the authors only utilized 18 strains (taking into account UBCF_13). It would be interesting to know what was the selection method of these strains performed by the authors.

Also, very importantly the sequence similarity cutoff for the pangenome analysis was provided (70\%) but not the sequence coverage which is crucial to understand how strict the clustering performed was in the pangenome analysis. Also, it would interesting to know why these cut-offs were selected.

Finally, a brief paragraph summarizing the conclusions obtained by the author after the result section would help wrap up the whole manuscript.

\section{References}

1. Hennessy RC, Dichmann SI, Martens HJ, Zervas A, et al.: Serratia inhibens sp. nov., a new antifungal species isolated from potato (Solanum tuberosum).Int J Syst Evol Microbiol. 2020; 70 (7): 4204-4211 PubMed Abstract | Publisher Full Text

\section{Is the rationale for creating the dataset(s) clearly described?}

No

Are the protocols appropriate and is the work technically sound?

No

Are sufficient details of methods and materials provided to allow replication by others? No

Are the datasets clearly presented in a useable and accessible format?

No

Competing Interests: No competing interests were disclosed.

Reviewer Expertise: Comparative genomics

I confirm that I have read this submission and believe that I have an appropriate level of expertise to state that I do not consider it to be of an acceptable scientific standard, for reasons outlined above. 
The benefits of publishing with F1000Research:

- Your article is published within days, with no editorial bias

- You can publish traditional articles, null/negative results, case reports, data notes and more

- The peer review process is transparent and collaborative

- Your article is indexed in PubMed after passing peer review

- Dedicated customer support at every stage

For pre-submission enquiries, contact research@f1000.com 